\title{
Students' Perception of Vodcast and Podcast as Instructional Material
}

\author{
Samuel Chukwuemeka Nwachokor ${ }^{1}$, Ifeoma Benardine Onah ${ }^{1}$, Patrick Oyaimare Uddin ${ }^{2}$ \\ ${ }^{1}$ University of Nigeria, Nsukka \\ Nsukka Road, 410001, Nsukka, Enugu State, Nigeria \\ ${ }^{2}$ Ambrose Alli University \\ 70 Benin Auchi Road, P. M. B 14, Ekpoma, Edo State, Nigeria
}

DOI: $10.22178 /$ pos. $47-5$

LCC Subject Category:

LB2331.7-2335.8

Received 28.05.2019

Accepted 25.06.2019

Published online 30.06.2019

Corresponding Author:

Patrick Oyaimare Uddin

uddinpatrick@gmail.com

(C) 2019 The Authors. This article

is licensed under a Creative

Commons Attribution 4.0 License

(c) (1)

\begin{abstract}
The study was conducted to examine students' perception of vodcast and podcast as instructional material. The study employed a survey research design. The total sample size for the study was two hundred and twenty-five (225) respondents. Data was analyzed and presented using mean statistic and standard deviation. Hypothesis for the study was analyzed using t-test with a $p \leq 0.05$ level of significance. Students in the study to a low extent $(=1.97)$ agreed that vodcast and podcast increase productivity, promote creativity and facilitate academic learning. Respondents are of the view that the University of Nigeria, Nsukka postgraduate program is not yet advanced enough to use vodcast and podcast technologies for teaching students $(=2.88)$. Unavailability of technologies had a significant influence on barriers that hinder students from using vodcast and podcast. Based on the findings and conclusion, it is recommended among others, that the University of Nigeria, Nsukka organize a capacity building workshop hinged on the use of top-notch technology for 21st century education; that departments in the university should motivate lecturers to employ technological tools in teaching through incentives as these will encourage every lecturer to key into the move.
\end{abstract}

Keywords: students' perception; media in education; pedagogic research; teaching/learning strategies.

\section{INTRODUCTION}

Perception is a function of simulation. It is when an individual maintains contact with his environment [1]. Author [2] sees perception as the cognitive processes of the brain at the subconscious. Students perceive online learning and its' associated technology as a strategic advantage to them because it is beneficial, convenient and enhances their communication and interaction level with their immediate and extended environment [3].

A student is a person under the control of those that have more experience in his area of interest [4]. Author [5] sees a student as one that is carrying out a study in a school such as colleges or universities. Today's students are demanding a change in the classroom due to their ability to gather information faster than any other generation [6] from the web. Author [7] shows that in- structional materials have an important influence on students' academic achievement.

Instructional material is any device with instructional content that is used for teaching purpose $[8,9]$ supported that Instructional materials refer to objects or devices that make a lesson much clearer to the learner. Author [10] sees instructional materials as objects or device which helps the teacher to make learning more meaningful to the learner. The use of instructional material in teaching and learning makes student to learn more and retain better what has been taught [11]. Authors [12] see instructional material as a didactic material which makes learning and teaching possible. Researcher [7] shows that instructional material and teaching methodology have great importance on student academic achievement. The use of instructional material makes learning real and not abstract [13, 14], moreover, pointed out that the use of instruc- 
tional materials enables the learner to participate actively in classroom instruction. Researchers [12] argued that instructional materials are not a replacement for teaching but a means of enhancement for better teaching of the student. $\mathrm{Au}-$ thor [15] explained that instructional materials are of different classes which are audio, visual or audio-visual. Researchers [16] affirm that instructional materials are those apparatus of teaching which may include chart, textbooks, workbook, audio-visual aids, etc.

Vodcast is a term used for online delivery of video content, this content is for registered students. According to [17] vodcast means video on demand. Vodcasting uses the enclosures of Real Simple Syndication (RSS) feeds for distribution of video content that can be downloaded to mobile devices [18]. Researchers [17] vodcast means video on demand [19] opined that Podcast creates better connections with students. Podcast creates interaction with the learner and the content.

The podcast was coined in 2004 to refer to audio files downloaded automatically using Real Simple Syndication software and played on Apple's iPod [20]. According to [21] podcast is an Internetbased means for broadcasting information. According to [22] podcast is a media file that can be audio and/or video and which can be automatically downloaded from the web to devices such as smartphones, PCs or mp3 players. The podcast is a series of audio files that can be downloaded from the internet, it schedules on a regular basis when it will be released [23]. Researchers [17] see vodcast as video on demand, while authors [24] see the podcast as audio file technology that can be downloaded to facilitate the delivery of instruction in both traditional and online course. Podcast has the potential to boost student knowledge construction in the socio-cognitive environment [19]. In [25] it was pointed out that students felt that lecturers using Podcast had more plan for their academic welfare and they are glad when lecturers make use of it. Authors [26] pointed out that Podcast can serve as a supplement to student textbooks. Researchers [12] in their work pointed out that educational software should have these five functions: drill, practice, tutorial, simulation/games and problemsolving. Podcast promotes continuous learning as it enhances self-revision. It also promotes flexible study as it is auto downloaded, the podcast can be restricted to the only student that registers for the course and podcast studio need not be ex- pensive. Researchers [20] pointed that podcast has several advantages such as lecturers using it to augment their teaching and to teach without restrictions in time or place, secondly, students appreciate learning on the go as they can repeat learning. There have been some little intricacies in Podcast [27], which are barriers in the increase of workload for the faculty who must learn the technology and upload audio files, understanding the basics of digital audio files, copyright issue, editing of recorded file consumes time and for the most part, podcast for students with disabilities are not achieved because they are not properly edited and these students can't contribute after it has been uploaded. Authors [20] stated that there are some downsides to the podcast which are reduced interaction between students and lecturers, the inability of students to ask questions, the inability of lecturers to gauge the understanding from non-verbal cues and questions. Students may be less engaged in the learning and motivation may suffer. It is important to note that vodcast is the video version of the podcast.

\section{Significance of the Study}

The finding on students' perception of vodcast and podcast as instructional material will be of great benefit to students in tertiary institutions in Nigeria at large, lecturers in higher institutions, curriculum planner(s) and government. The findings from this study will serve as an eye-opener to the numerous advantages provided when using vodcast and podcast as instructional material. Students will benefit from this study in that it will provide adequate techniques of studying to a mastering level. This new technology can be used to force the learner to follow a strict sequence of the lesson in addition to learning at his pace.

The findings of the study would provide curriculum planners with the information needed to enrich future trends in the curriculum; it will also unravel podcast as an instructional material when employed in teaching, will reduce the declining overall performance of students.

The pedagogical skills of lecturers will improve on the use of instructional materials if the findings from this study are well implemented. The students' interaction with vodcast and podcast will afford the lecturers great opportunity in the use of vodcast and podcast as a learning medium, which would transform the present isolated lec- 
turer centered and text-bound classroom into a rich student-centered and interactive knowledge based on an environment that would enhance students' cognitive achievement and retention as well as serve as a psychomotor achievement and retention

The result of this study will assist the government in the pursuit of quality education, as well as help upgrade the teaching facilities in our various institutions to enable the use of latest 21st-century instructional materials in our schools.

\section{Statement of Problem}

Instructional delivery is a means of transferring knowledge and skills with ease using different medium and forms of technology possible. A lot of majority of the lecturers have not updated their lesson notes because they are not challenged about how they teach. Researchers [28], in their study were able to reveal that in the space of ten (10) years, acceptance for online teaching has only risen from $27.6 \%$ in 2002 to $30.2 \%$ in 2012 , but when the various lessons they teach is being recorded and uploaded for everyone to download with link, there will be a proper day to day upgrading with new innovations on their various lessons. Some researchers have been able to point out that the percentage of the student using the internet is more than the number of the student using the library. Thus, this is the way out for most students faced with the problem of not understanding the note given to them. Children have access to the internet almost everywhere they go and use it almost every day [29] because they are either slow learners or the note giving isn't self-explanatory, but with the lecturer links they will be able to go over it after class as many times as possible till they have a proper understanding of the class.

\section{Purpose of the Study}

The purpose of this study is to ascertain students' perception of vodcast and podcast as instructional material. Specifically, the study is to:

1. Determine students' perception of lecturers' use of vodcast and podcast in teaching and learning.

2. Ascertain students' perception of lecturers' classroom use of vodcast and podcast.
3. Determine barriers militating against students' use of vodcast and podcast.

\section{Hypothesis}

1. There is no significant difference between the mean responses of Ph.D. and MSc students on lecturers' use of vodcast and podcast in teaching and learning.

2. There is no significant difference between the mean responses of Ph.D. and MSc students' perception of lecturers' classroom use of vodcast and podcast.

3. There is no significant difference between the mean responses of Ph.D. and MSc students on barriers militating against students' use of vodcast and podcast.

\section{Scope of the Study}

This study is focused on students' perception of the use of vodcast and podcast as intructional material among postgraduate students who occupied the University of Nigeria, Nsukka, Odili postgraduate hall of residence in the 2016/2017 academic session.

\section{Methodology}

The descriptive survey research design was adopted in carrying out this research. The descriptive survey is a study that entails the systematic collection of data to give a clear picture of a particular situation [30]. The rationale is that the study aims at collecting data and examines the student perception of vodcast and podcast as instructional material.

The population of this study is made up of (517) five hundred and seventeen occupants of Odili Hostel 2016/2017 session of University of Nigeria, Nsukka. Yaro Yamane was used for the sampling, this study is comprising of (225) two hundred and twenty-five Post-graduate students that are an occupant of the Odili Hall of University of Nigeria, Nsukka. The respondents which comprise of Post-graduate students (Masters and Ph.D.) from various field cutting from seven (7) faculties (agriculture, arts, education, engineering, pharmacy, biological science, and social science) will help get a different perception of students on the use of vodcast and podcast as instructional material to aid learning. 
The research instrument used in collecting the data is the questionnaire and it was titled Student perception of Vodcast and Podcast as an Instructional Material. The questionnaire consists of 25 questions based on the research questions drawn. The questionnaire was validated by two lecturers from the faculty of vocational and technical education after which the questionnaire was administered. Mean was used to determine the research questions on student's perception on Vodcast and Podcast as an instructional mate- rial and standard deviation was used to point out the response of respondents from group mean, while t-test was used to test the level of significance of the null hypotheses at a level of 0.05 level of significance was used to determine if it will be accepted or rejected.

\section{RESULTS AND DISCUSSION}

The results for the first question and the first hypothesis are presented in Table 1.

Table 1 - Students rating of lecturers' use of vodcast and podcast in teaching and learning

\begin{tabular}{|l|l|c|c|c|c|c|}
\hline No & \multicolumn{1}{|c|}{ Items } & $\mathrm{X}$ & SD & Decision & Sig & Remark \\
\hline 1 & $\begin{array}{l}\text { Choice of vodcast and podcast system resource and } \\
\text { services }\end{array}$ & 2.52 & 1.10 & $\mathrm{M} \mathrm{E}$ & 0.07 & $*$ \\
\hline 2 & $\begin{array}{l}\text { Understanding ethics, legal issues related to vodcasting } \\
\text { and podcasting }\end{array}$ & 2.89 & 0.96 & $\mathrm{M} \mathrm{E}$ & 0.23 & $*$ \\
\hline 3 & Troubleshooting vodcast and podcast related problems & 2.91 & 1.00 & $\mathrm{M} \mathrm{E}$ & 0.27 & $*$ \\
\hline 4 & $\begin{array}{l}\text { Use of various variants of vodcast and podcast to } \\
\text { collaborate, publish and interarct with students, } \\
\text { colleagues and other audience }\end{array}$ & 2.15 & 0.87 & $\mathrm{~L} \mathrm{E}$ & 0.57 & $*$ \\
\hline 5 & $\begin{array}{l}\text { Use of vodcast and podcast to increase productivity, } \\
\text { promote creativity and facilitate academic learning } \\
\text { Cluster Mean }\end{array}$ & 1.97 & 0.99 & $\mathrm{~L} \mathrm{E}$ & 0.67 & $*$ \\
\hline
\end{tabular}

Notes: * indicate values not significant at $5 \%$ probability level, , M E = Moderate Extent and LE = Low Extent

Table 1 presents the mean rating of respondents on the usefulness of vodcast and podcast in teaching and learning. Items 1-3 show a moderate extent because the mean is above 2.50 while item 4 and item 5 score was below the cutoff point hence it was low extent. The standard deviation values from the 5 items ranged from 0.87 to 1.10 which shows that the response was close to one and other. Hence from the cluster mean it had a mean of 2.57 and a standard deviation of 0.76 indicating the moderate extent of usefulness of vodcast and podcast in teaching and learning. The data in Table 1 showed the significant difference between the responses of Ph.D. and MSc students on the usefulness of vodcasting and podcasting, the cluster mean sig value of 0.250 was obtained. Since the sig value of 0.250 is greater than the alpha value of 0.05 set as the level of significance for testing hypothesis, the null hypothesis which stated that there is no significant difference between the responses of Ph.D. and MSc students on the usefulness of vodcasting and podcasting is retained.

The results for the second question and the second hypothesis are presented in Table 2.
Table 2 presents the mean rating of the options of the respondents on the extent students can perceive their lecturers class room usage of vodcast and podcast technology. Items 6, 8 and 10 show that it is in moderation because the mean is above 2.50 while item 7 and item 9 scores were below the criterion hence it was low extent. The standard deviation valued from the 5 items ranged from 0.83 to 1.10 which show that the responses were close to one and other. Hence from the cluster mean it had a mean of 2.66 and a standard deviation of 0.50 indicating moderate extent of how students' perception about lecturer's classroom usage of Vodcast and Podcast. The data in Table 2 showed the significant relationship between students' perception and lecturer's class room usage of vodcast and podcast technology. The cluster mean sig value of 0.056 was obtained. Since the probability of 0.056 is greater than 0.05 set as level of significance for testing hypothesis, the null hypothesis which states that there is no significant relationship on how students perceive their lecturer's classroom usage of podcast technology is retained. 
Table 2 - Students' perception of lecturers' classroom uses of vodcast and podcast

\begin{tabular}{|l|l|c|c|c|c|c|}
\hline No & \multicolumn{1}{|c|}{ Items } & $\mathrm{X}$ & SD & Decision & Sig & Remark \\
\hline 6 & $\begin{array}{l}\text { Lecturers are more engaged in teaching due to vodcasting and } \\
\text { podcasting }\end{array}$ & 3.18 & 0.83 & $\mathrm{M} \mathrm{E}$ & 0.854 & $*$ \\
\hline 7 & $\begin{array}{l}\text { Vodcasting and podcasting help lecturers to improve on other } \\
\text { basic computer skills/programs }\end{array}$ & 2.23 & 0.89 & $\mathrm{LE}$ & 0.042 & $* *$ \\
\hline 8 & Lecturers sparingly use vodcast and podcast during lectures & 2.93 & 0.86 & $\mathrm{M} \mathrm{E}$ & 0.119 & $*$ \\
\hline 9 & Most lecturers use computers only in the office & 2.44 & 1.10 & $\mathrm{LE}$ & 0.751 & $*$ \\
\hline 10 & $\begin{array}{l}\text { Lecturers participate actively in distance learning programs of } \\
\text { other institutions with the aid of vodcast and podcast }\end{array}$ & 2.64 & 0.87 & $\mathrm{M} \mathrm{E}$ & 0.252 & $*$ \\
\hline & Cluster Mean & 2.66 & 0.50 & $\mathrm{M} \mathrm{E}$ & 0.056 & $*$ \\
\hline
\end{tabular}

Notes: * Not significant and ** significant, M E Moderate Extent and L E = Low Extent

The results for the third question and the third hypothesis are presented in Tables 3-4.

Table 3 presents the mean rating of the respondents on the challenges that hinder students from using vodcast and podcast. Items 11, 12, 13 and 14 were rejected because their mean is below 2.50 while item 15 and item 16 score were above the criterion hence it was accepted. The standard deviation values from the 6 items ranged from 0.80 to 1.22 which shows that the responses were close to one another. Items 17 , $18,19,20,24$ and 25 were rejected because the mean is below 2.50 while item 21, 22 and 23 score was above the criterion hence it was accepted.

Table 3 - Barriers militating against students' use of vodcast and podcast

\begin{tabular}{|c|l|c|c|c|c|c|}
\hline No & \multicolumn{1}{|c|}{ Items } & Mean & SD & Decision & Sig & Remark \\
\hline 11 & Inadequate ICT infrastructure & 2.28 & 0.96 & $\mathrm{R}$ & 0.97 & $*$ \\
\hline 12 & $\begin{array}{l}\text { Poor orientation of students toward the use of vodcast and } \\
\text { podcast technologies }\end{array}$ & 2.10 & 0.80 & $\mathrm{R}$ & 0.69 & $*$ \\
\hline 13 & $\begin{array}{l}\text { Poor attitude of lecturers towards the use vodcast and podcast in } \\
\text { the classroom }\end{array}$ & 2.18 & 0.98 & $\mathrm{R}$ & 0.27 & $*$ \\
\hline 14 & $\begin{array}{l}\text { Most lecturers don't know about vodcast and podcast } \\
\text { technologies }\end{array}$ & 2.05 & 1.12 & $\mathrm{R}$ & 0.93 & $*$ \\
\hline 15 & $\begin{array}{l}\text { The School of Postgraduate Studies (SPGS) in the University of } \\
\text { Nigeria, Nsukka is not fully equipped to use ICTs for teaching and } \\
\text { learning activities }\end{array}$ & 2.88 & 1.22 & $\mathrm{~A}$ & 0.28 & $*$ \\
\hline 16 & $\begin{array}{l}\text { Inadequate technical support by staff in the ICT department in } \\
\text { the use of vodcast and podcast }\end{array}$ & 2.80 & 1.05 & $\mathrm{~A}$ & 0.08 & $*$ \\
\hline
\end{tabular}

Notes: * Indicate values not significant at $5 \%$ probability level, $R=$ Reject and $A=$ Accept

Table 4 - Vodcasting and podcasting equipments available for use in the classrooms

\begin{tabular}{|l|l|c|c|c|c|c|}
\hline No & \multicolumn{1}{|c|}{ Items } & Mean & SD & Decision & Sig & Remark \\
\hline 17 & Computer & 2.09 & 0.87 & R & 0.49 & $*$ \\
\hline 18 & Internet & 2.07 & 0.84 & $\mathrm{R}$ & 0.18 & $*$ \\
\hline 19 & Overhead projectors & 2.22 & 0.85 & $\mathrm{R}$ & 0.88 & $*$ \\
\hline 20 & Electronic mail & 2.13 & 0.69 & $\mathrm{R}$ & 0.82 & $*$ \\
\hline 21 & iPod & 2.80 & 0.99 & $\mathrm{~A}$ & 0.08 & $*$ \\
\hline 22 & Video software & 2.71 & 0.96 & $\mathrm{~A}$ & 0.44 & $*$ \\
\hline 23 & Video cameras & 2.82 & 1.63 & $\mathrm{~A}$ & 0.48 & $*$ \\
\hline 24 & Television & 2.42 & 0.91 & $\mathrm{R}$ & 0.23 & $*$ \\
\hline 25 & Distant learning equipment and infrastructure & 2.36 & 0.99 & $\mathrm{R}$ & 0.38 & $*$ \\
\hline & Cluster Mean & 2.43 & 0.49 & $\mathrm{R}$ & 0.14 & $*$ \\
\hline
\end{tabular}

Notes: * Indicate values not significant at $5 \%$ probability level, $R=$ Reject and $A=A c c e p t$ 
The standard deviation values from the 9 items ranged from 0.69 to 1.63 which shows that the responses were close to one another. Hence from the cluster mean it had a mean of 2.43 and a standard deviation of 0.49 indicating reject of challenges that hinders students from using vodcast and podcast. The cluster means a sig value of 0.079 was obtained. Since the probability of 0.079 is greater than 0.05 set as the level of significance for testing hypothesis, the null hypothesis which stated that there is no significant relationship between equipment available and instructional delivery is significant retained.

The mean responses of Ph.D. and M.Sc students on the barriers hindering vodcasting and podcasting as instructional materials.

The finding revealed from Table 1 and Table 2 as the moderate extent of mean response of students on the usefulness of vodcast and podcast in teaching and learning and student perception about lecturer's classroom usage of vodcast and podcast respectively item 4, 5, 7 and 9 indicated low extents. However, the cluster t- value is 1.156 and 1.929 respectively with a degree of freedom 115 and 120 respectively and with a significance of 0.250 and 0.056 respectively was obtained. Since the sig value is greater than the alpha value it is significant. The null hypothesis was rejected.

The findings from Table 3 revealed that the responses rejected Barriers that hinders Students from using vodcast Podcast. How the Cluster tvalue is -0.477 and -1.772 respectively with a degree of freedom 141 and 99 respectively and with a significance of 0.634 and 0.079 respectively was obtained. Since the sig value is greater than the alpha value it is significant, the null hypothesis that was stated will be rejected.

\section{CONCLUSION}

The application of technological innovation in education is of great essence needed by students to compete in a bigger society. This research is focused on students' perception of vodcast and podcast as instructional material. From the findings in the study, lecturers were yet to fully adopt vodcast and podcast as instructional material in teaching and learning. Students were of the view that the Univeristy of Nigeria, Nsukka school of postgraduate studies (SPGS), is not fully equipped to engage technological innovations in teaching students. From the foregoing, it is recommended that, University of Nigeria, Nsukka organize capacity building workshops to train, educate and enlighten lecturers on the need to use vodcast and podcast in teaching students. Also, the university should invest in ICTs infrastructure to ameliorate some of the barriers hindering students from effectively using vodcast and podcast in their academic pursuit.

\section{REFERENCES}

1. Richards, R. J. (1976). James Gibson's Passive Theory on Perception: A Rejection of the Doctrine of specific Nerves Energies. Philosophy and Phenomenological Research, 37(2), 218-233. doi: $10.2307 / 2107193$

2. Wang, Y. (2007). On the Cognitive Processes of Human Perception with Emotions, Motivations, and Attitudes. International Journal of Cognitive Informatics and Natural Intelligence, 1(4), 1-13. doi: 10.4018/jcini.2007100101

3. Ciampa, M., \& Revels, M. (2012). Student access to online interaction technologies: The impact on grade delta variance and student satisfaction. Retrieved from https://www.westga.edu/ distance/ojdla/winter154/ciampa_revels154.html

4. Obayi, P.N. (2013, February). Utilization of computer as a tool for computing students' results in tertiary institutions in Enugu state (Master's thesis). Retrieved from http://www.unn.edu.ng/publications/files/Utilization\%20of\%20Computer\%20as\%20a\%20To ol\%20\%20-\%200bayi\%20Priscilla\%20N..pdf

5. Onah, B.I. (2012). Development and validation of an electronic learning (e-learning) programme for the digital empowerment of students in south east, Nigeria. Retrieved from https://freeresearchproject.com.ng/research/development-and-validation-of-an-electronic- 
learning-e-learning-programme-for-the-digital-empowerment-of-students-in-south-eastnigeria/

6. Blackboard, (2010). Improving classroom learning. Retrieved from https://www.blackboard.com/resources/k12/K12_Improving_Classroom_Learning.pdf

7. Afe, J. O. (2001). Reflections of becoming a teacher and the challenges of teacher education. In Inaugural Lecture Series 64. Benin City: University of Benin.

8. Adebipme, A. O. (1997). Improvisation of Science Teaching Resources. In Proceeding of 40th Annual Conference of STAN (pp. 55-60). Kano.

9. Isola, O.M. (2010). Effects of standardized and improvised instructional materials. Students' academic achievements in secondary school physics (M.Ed. thesis), University of Ibadan.

10. Ikerionwu, J. C. (2000). Importance of aids and resources in classroom teaching. In A. M. Oyeneyin (Ed.), Perspectives of classroom teaching (pp. 141-165). Abuja: Martmonic Investment Ltd.

11. Adebanjo, A. A. (2007). Effect of instructional media on the learning of computer in JSS. African Journal of Education Research, 1(2), 71-75.

12. Nwachokor, S., Abu, T., \& Arasi, F. (2019). Utilization of software instructional material in government secondary school in Uvwie local government area of delta state. Retrieved from https://www.researchgate.net/project/utilization-of-software-instructional-material-ingovernment-secondary-school-in-uvwie-local-government-area-of-delta-state

13. Lucas, O. T. (2015). Effect of instructional materials and teaching methodology on mathematics achievement among senior secondary school students in Lagos Nigeria. Journal of Education Review, 8(2), 157-167.

14. Igu, N.C., Ogba, F. N, \& Igwe, I. O. (2014). Effects of instructional materials on students' achievement in social studies in lower basic education in Nigeria. Retrieved from

https://docplayer.net/37271753-Effects-of-instructional-materials-on-students-achievementin-social-studies-in-lower-basic-education-in-nigeria.html

15. Agina-Obua, T. N. (2005). The relevance of instructional materials in teaching and learning. In I. Robert-Okah, K. Uzoechi (Eds.), Theories and Practice of Teaching (pp. 9-12). Port Harcourt: Harey Publications.

16. Agwu, S. N. (Ed.). (2001). Teaching in Nigeria. A dynamic approach. Enugu: Cheston Nigeria Ltd.

17. Ronco, C. \& Scabardi, M. (2016). Vodcasting: The story behind Cappuccino. ICU Management and Practice, 16(2), 1-4.

18. Gkatzidou, S., \& Pearson, E. (2007). Vodcasting: A case study in adaptability to meet learners' needs and preferences. Retrieved from

http://www.ascilite.org/conferences/singapore07/procs/gkatzidou.pdf

19. Long, R. \& Fabry, D. (2011). Exploring podcasting of required reading in a graduate counseling course. Perspectives in Learning, 12(1), 13-20.

20. Schreiber, B. E., Fukuta, J., \& Gordon, F. (2010). Live lecture versus video podcast in undergraduate medical education: A randomised controlled trial. BMC Medical Education, 10(1). doi:

10.1186/1472-6920-10-68

21. Li, H. (2010). Using podcasts for learning English: perceptions of Hong Kong secondary 6 ESL students. Début: the undergraduate journal of languages, linguistics and area studies, 1(2), 78-90.

22. Alarcón, R., Blanca, M. J., \& Bendayan, R. (2017). The Student Satisfaction with Educational Podcasts Questionnaire. Escritos de Psicología / Psychological Writings, 10(2), 126-133. doi: 10.5231/psy.writ.2017.14032

23. Overmyer, G. (2010). The impact of mastery learning and video podcasting on learner performance in secondary mathematics: Pre-vodcasting and the reverse classroom. Content Preliminary Examination, School of Education, Colorado State University. 
24. Traphagan, T., Kucsera, J. V., \& Kishi, K. (2009). Impact of class lecture webcasting on attendance and learning. Educational Technology Research and Development, 58(1), 19-37. doi: 10.1007/s11423-009-9128-7

25. Forbes, M. O., \& Hickey, M. T. (2008). Podcasting. Nurse Educator, 33(5), 224-227. doi: 10.1097/01.nne.0000334775.98018.e8

26. Masudul Hasan, M., \& Bee Hoon, T. (2013). Podcast Applications in Language Learning: A Review of Recent Studies. English Language Teaching, 6(2). doi: 10.5539/elt.v6n2p128

27. Campbell, G. (2005). There's something in the air: Podcasting in education. Educause Review, 40(6), 32-47.

28. Allen, I. E., \& Seaman, J. (2013, January). Changing course: Ten years of tracking online education in the United States. Retrieved from https://www.onlinelearningsurvey.com/reports/changingcourse.pdf

29. Hill, B. (2017). Parents perceptions of the internet and its effects on their children. Honors Theses. Retrieved from https://scholar.utc.edu/cgi/viewcontent.cgi?article=1102\&context=honorstheses

30. Ukonze, J. A. (2013). Capacity building needs of women farmers in cocoa processing enterprise for food security in Abia State. Retrieved from https://www.researchgate.net/publication/273493498_CAPACITY_BUILDING_NEEDS_OF_WO MEN_FARMERS_IN_COCOA_PROCESSING_ENTERPRISE_FOR_FOOD_SECURITY_IN_ABIA_STATE 